\title{
Growth Promoting Microorganisms for Treatment of Soybean Seeds
}

\author{
Isledi William da Silva ${ }^{1}$, Patrícia Carine Hüller Goergen ${ }^{2}$, Luiz Volney Mattos Viau', \\ Sandra Beatriz Vicenci Fernandes ${ }^{3}$, José Antônio Gonzalez da Silva ${ }^{3}$ \\ $\&$ Cleusa Adriane Menegassi Bianchi ${ }^{3}$ \\ ${ }^{1}$ Graduate in Agronomy, Regional University of the Northwest of the State of Rio Grande do Sul, Ijuí, Brazil \\ ${ }^{2}$ Postgraduate Program in Agronomy, Federal University of Santa Maria, Santa Maria, Brazil \\ ${ }^{3}$ Department of Crop Science, Regional University of the Northwest of the State of Rio Grande do Sul, Ijuí, Brazil \\ Correspondence: Patrícia Carine Hüller Goergen, Avenida Roraima, no 1000, Bairro Camobi, CEP 97105-900, \\ Santa Maria, RS, Brazil. Tel: 55-99139-7063. E-mail: patygoergen@hotmail.com
}

\author{
Received: March 7, $2018 \quad$ Accepted: April 8, $2018 \quad$ Online Published: May 15, 2018 \\ doi:10.5539/jas.v10n6p198 URL: https://doi.org/10.5539/jas.v10n6p198
}

\begin{abstract}
The use of microorganisms that promote plant growth is an important tool for increasing agricultural production; besides, there is an emerging demand for decreasing utilization of chemical fertilizers and to solidify sustainable agriculture. The objective of this study was to evaluate the efficacy of growth promoting microorganisms Bradyrhizobium elkanii and Trichoderma harzianum for treatment of soybean seeds. This experiment was conducted at the Regional Institute of Rural Development (IRDeR), in Augusto Pestana, RS, Brazil. The experimental design was randomized blocks and treatments were: control, Trichoderma harzianum, Bradyrhizobium elkanii, and co-inoculated Trichoderma harzianum + Bradyrhizobium elkanii, with four replications per treatment. The sample units were five rows $5 \mathrm{~m}$ in length, spaced at $0.5 \mathrm{~m}$, and three central lines were used to analyze the components of soybean yield. Of these, two lines were harvested $4 \mathrm{~m}$, and the incidence of soil diseases in the plants was evaluated in one of the lines. Treatments means were compared using Tukey test. There was an effect of treatments: B. elkanii and treatment with co-inoculation B. elkanii and T. harzianum showed a significant response to grain yield. The chemical treatment without microorganisms with a biological effect had a higher incidence of diseases and a lower yield of grains.
\end{abstract}

Keywords: Glycine max, Trichoderma harzianum, Bradyrhizobium elkanii, inoculation, soil fungi

\section{Introduction}

Soybeans (Glycine max L.) cultivation is economically important for Rio Grande do Sul state, Brazil (Ribeiro et al., 2017). In the region of Alto Uruguai, this oilseed was introduced in 1936 to feed pigs, when pig farming was the main activity in the region. Thereafter, growing soybeans in the state became increasingly popular and in the 1970 this crop accounted for nearly $40 \%$ of the cultivated area (Caldarelli, Câmara, \& Sereia, 2009; Freitas, 2011). This was due to favorable environmental conditions for cultivating soybeans, corn (Zea mays) and wheat (Triticum aestivum) that, when integrated together, support soil conservation practices and increase nitrogen in the soil, resulting in better soil fertility (Caldarelli, Câmara, \& Sereia, 2009; Andrade et al., 2016). In Brazil, soybeans are integrated into practically every production unit, provide additional income for farmers, are processed and sold domestically or exported internationally, and generate more than a million direct and indirect jobs throughout the country (Dotto et al., 2015; Ribeiro et al., 2017).

Successful cultivation of soybeans requires high-quality seeds and adopts a management strategy that ensure germination and emergence of seedlings, providing an adequate population of the crop (Mertz et al., 2009). When soybeans encounter adverse edaphoclimatic conditions farmers must replant the crop, which can increase production costs and damage the production potential of the tillage (Schuab et al., 2008; Rocha et al., 2017).

Beyond the seeds, the soil and crop remnants can be sources of inocula, and plants will be susceptible to pathogens (frequently Phythophthora sojae, Fusarium spp, Sclerotinia sclerotiorum and Macrophomina phaseolina), which reduce productivity (Danelli et al., 2011). The frequent introduction of seeds infected by pathogens tends to increase sources of inoculum in the soil and microorganisms will reduce yield and quality of seeds (Lucca et al., 2008; Ethur et al., 2016). 
To neutralize the pathogenic action of fungi and bacteria, seeds should be treated before planting using mainly chemical fungicides, antagonistic organisms, and plant growth promoters. This method is effective for fungi control because it is localized in the seed and reduces the use of agrotoxins (Danelli et al., 2011; Mertz et al., 2009). Trichoderma spp. based products are effective at controlling soil phytopathogens and are marketed globally because they possess high antagonistic and mycoparasitic potential and can reduce severity of plant diseases, by inhibiting phytopathogens in the soil and roots (Brotman et al., 2013).

An important characteristic of Fabaceae is to dispense fertilizing nitrogen, because roots of plants have specialized structures, called nodules, which fix biological $\mathrm{N}$ (FBN) by transforming atmospheric $\mathrm{N}$ into organic compounds assimilated by the plants (Brandelero, Peixoto, \& Ralisch, 2009). Thus, chemical fertilizers (e.g., urea) with high losses from volatilization and leaching are serious environmental risks (e.g., eutrophication of rivers, lakes and springs), and should not be used. Thus, the farmer decides to inoculate seeds with specific bacteria (e.g., genus Bradhirizobium), which besides fixing $\mathrm{N}_{2}$, stimulate growth of root hairs and formation of secondary roots that help absorbing nutrients and water; thus, there is greater capacity to withstand hydric stress and an increase in productivity (Zilli et al., 2008; Silva et al., 2011; Teixeira et al., 2014).

Strategies that use microorganisms represent economic and ecologically correct alternatives for increasing soybean production, in addition to preventing human intoxication by agrotoxins. Therefore, the objective of this research was to study the interactions of soybean seeds inoculated with fungus Trichoderma harzianum and bacteria Bradhirizobium elkanii, to evaluate their antagonistic effect on pathogens for soybean crop, increment of soybean production and reduction of diseases incidence in plants and soil fungi.

\section{Material and Methods}

The experiment was conducted in the municipality of Augusto Pestana, Rio Grande do Sul, Brazil, in a field without irrigation during the 2015/2016 harvest. Seeds were sown in the first half of December 2015 at the Instituto Regional de Desenvolvimento Rural (IRDeR) ( $28^{\circ} 26^{\prime} 30^{\prime \prime} \mathrm{S}, 54^{\circ} 00^{\prime} 58^{\prime \prime} \mathrm{W}$, altitude ca. $300 \mathrm{~m}$ ).

The climate in the region is Cfa, subtropical humid, according to the Köppen classification, with a hot, dry and average annual rainfall of $1600 \mathrm{~mm}$. The soil is classified as a typical dystrophic red latosol originating from the basalt formation of the Serra Geral, characterized by its deep, dark red coloration and clay texture with a predominance of clay minerals and iron oxyhydroxides (1:1) (Santos et al., 2013).

The experimental design was a randomized block with four replications of treatments: Trichoderma harzianum, Bradyrhizobium elkanii and co-inoculated Trichoderma harzianum + Bradyrhizobium elkanii (Table 1). The plots were five rows of plants, $5 \mathrm{~m}$ long and $0.50 \mathrm{~m}$ apart. For sanitary analysis of the plants, at the end of the cycle and harvest, the plants of one of the $5 \mathrm{~m}$ rows were carefully removed from the soil and submitted to an in situ analysis of pathogens severity in the root system. Plants under attack by diseases and healthy plants were enumerated. Another two rows were harvested to estimate grain yield and the remaining rows were considered the border.

Table 1. Dosage and active principles used in the treatments ( $\mathrm{mL} \mathrm{kg}^{-1}$ seeds)

\begin{tabular}{|c|c|c|c|c|c|c|}
\hline Treatment & Active ingredient (i.a.) & \multicolumn{5}{|c|}{ Product dosage (mL kg ${ }^{-1}$ seeds) } \\
\hline $\mathrm{T} 1$ & Tiometoxan+Fludioxonil+Fipronil & 2.5 & 1.0 & 1.0 & 1.0 & \\
\hline $\mathrm{T} 2$ & Tiometoxan+Fludioxonil+Fipronil+Trichoderma harzianum & 2.5 & 1.0 & 1.0 & 1.0 & \\
\hline $\mathrm{T} 3$ & Tiometoxan+Fludioxonil+Fipronil+Bradyrizobium elkani & 2.5 & 1.0 & 1.0 & 1.0 & \\
\hline $\mathrm{T} 4$ & Tiometoxan+Fludioxonil+Fipronil+T. harzianum + B. elkani & 2.5 & 1.0 & 1.0 & 1.0 & 1.0 \\
\hline
\end{tabular}

Note. Commercial product: Cruiser (Tiametoxan); Maxim XL (Fludioxonil); Standak (Fipronil); Trichodermil (Trichoderma harzianum); Sys LL (Bradyrhizobium elkanii).

The seeds used were from the cultivar Don Mario 5958 RSF IPRO, which were industrially treated by the Costa Beber company in Condor, RS. They have been treated with the Sys LL product (Bradirizobium elkani): solid biological formulation developed for application in seed treatment, which protects against the action of phytosanitary agents, and extends the life of the bacteria on the seeds. The commercial product Trichodermil (Trichoderma harzianum) was also applied to the seeds before sowing, with the aid of a sprayer, at the dosage described in Table 1. This product was available from the IRDeR. 
The area was demarcated with a seeder to manually sow the seeds and $250 \mathrm{~kg} \mathrm{ha}^{-1}$ of $05-20-20\left(\mathrm{~N}-\mathrm{P}_{2} \mathrm{O}_{5}-\mathrm{K}_{2} \mathrm{O}\right)$ chemical fertilizer was added to the soil. The space between rows was $0.5 \mathrm{~m}$, with 13 seeds per linear meter, for a final population of 250,000 plants $\mathrm{ha}^{-1}$.

At stage R2, six plants per plot were collected for each repetition of the treatments of Bradyrhizobium elkanii (Cruiser + MaximXL + Standak + Bradyrhizobium elkanii) and control (Cruiser + Maxim + Standak), to quantify the number of nodules on the main and secondary roots.

The evaluation of soil diseases in plants was conducted in the first half of April 2016. Two hundred and twenty five plants per treatment (mean of 56 plants per plot) were evaluated to quantify the number of healthy plants and number of diseased plants. For the evaluation of yield components: mass of a thousand grains of healthy plants (MTGHP), mass of a thousand grains of diseased plants (MTGDP), number of grains of healthy plants (GHP), number of grains of diseased plants (GDP), number of legumes of healthy plants (LHP) and number of legumes of diseased plants (LDP), were randomly collected by plot two plants (healthy and diseased). The two rows used to analyze grain yield (GY), apparent biological yield (ABY) and straw yield (SY) were collected in the first half of April 2016.

The data were submitted to an ANOVA, and the yield averages (number of grains per plant, number of legumes, seeds per legume and mass per thousand grains) were compared using Tukey's test $(\mathrm{p} \leq 0.05)$. Besides, magnitude and direction of the associations between the variables of interest were determined. The hypotheses were tested using $t$ test $(\mathrm{p} \leq 0.05)$, with $\mathrm{n}-2$ degrees of freedom and the model (1), where $\mathrm{r}$ is the correlation coefficient between $\mathrm{X}$ and $\mathrm{Y}$ and $\mathrm{n}=$ degree of freedom of the treatment levels considered (Silva \& Azevedo, 2016).

$$
\mathrm{t}=\mathrm{r} /\left[\sqrt{\left(1-\mathrm{r}^{2}\right) /(\mathrm{n}-2)}\right]
$$

\section{Results and Discussion}

There were significant effects for grain yield, disease incidence, number of legumes on healthy plants and diseased plants, and number of grains of healthy plants and number of grains of diseased plants. There were no significant differences for apparent biological yield, straw yield, harvest index (HI), number of grains of diseased plants, average mass per thousand grains of healthy and diseased plants, weight of healthy plants (WHP) and weight of diseased plants (WDP) (Table 2).

Table 2. Summary of the analysis of variance for the components of yield evaluated, submitted to different treatments of seeds to control pathogens in soybean

\begin{tabular}{llll}
\hline \multirow{2}{*}{ Source of variation } & \multicolumn{2}{c}{ Mean Square } & CV\% \\
\cline { 2 - 4 } GY $(\mathrm{kg} / \mathrm{ha})$ & Treatments & 34812 & 4 \\
DI $(\%)$ & $437089^{*}$ & 169 & 21 \\
ABY $(\mathrm{kg} / \mathrm{ha})$ & $752^{*}$ & 592073 & 6 \\
SY $(\mathrm{kg} / \mathrm{ha})$ & $901295^{\mathrm{ns}}$ & 443848 & 10 \\
HI $(\%)$ & $227281^{\mathrm{ns}}$ & 29 & 11 \\
LHP $\left(\mathrm{n}^{\circ}\right)$ & $44^{\mathrm{ns}}$ & 33 & 7 \\
LDP $\left(\mathrm{n}^{\mathrm{o}}\right)$ & $1288^{*}$ & 64 & 14 \\
GHP $\left(\mathrm{n}^{\mathrm{o}}\right)$ & $354^{*}$ & 301 & 10 \\
GDP $\left(\mathrm{n}^{\mathrm{o}}\right)$ & $8177^{*}$ & 298 & 16 \\
MTGHP $(\mathrm{g})$ & $3162^{\mathrm{ns}}$ & 53 & 4 \\
MTGDP $(\mathrm{g})$ & $198^{\mathrm{ns}}$ & 108 & 6 \\
WHP $\left(\mathrm{n}^{\mathrm{o}}\right)$ & $22^{\mathrm{ns}}$ & 11 & 14 \\
WDP $\left(\mathrm{n}^{\circ}\right)$ & $28^{\mathrm{ns}}$ & 3 & 12 \\
\hline
\end{tabular}

Note. ${ }^{*} \mathrm{p} \leq 0.05$ (F test); ns: $\mathrm{p}>0.05$ (F test). CV: Coefficient of variation (\%); GY: Grain yield; DI: Diseases incidence; MTGHP: Mass of a thousand grains of healthy plants; MTGDP: Mass of a thousand grains of diseased plants; GHP: Number of grains of healthy plants; GDP: Number of grains of diseased plants; LHP: Number of legumes of healthy plants; LDP: Number of legumes of diseased plants; WHP: Weight healthy plant; WDP: Weight diseased plant; ABY: Apparent biological yield; SY: Straw yield; HI: Harvest index; no : number; g: grams; CV: Coefficient of variation. 
According to Oliveira et al. (2009) and Pimentel-Gomes (2009), the coefficients of variation (CV) are within the statistical patterns recommended for this type of experiment for the variables evaluated. In this experiment all variables evaluated had low $\mathrm{CV}$, indicating high experimental precision.

For grain yield, Tiametoxan + Fludioxonil + Fipronil + Bradyrhizobium elkanii had higher productivity $(4,451$ $\left.\mathrm{kg} \mathrm{ha}^{-1} ; 17.29 \%\right)$ higher than the control, but it was similar to Tiametoxan + Fludioxonil + Fipronil + Trichoderma harzianum + Bradyrhizobium elkanii $\left(4,227 \mathrm{~kg} \mathrm{ha}^{-1}\right)$ (Table 3). Indicating that soybean seeds inoculated with fungus Trichoderma harzianum and bacteria Bradhirizobium elkanii increment of soybean production.

Table 3. Grain yield, diseases incidence, apparent biological yield, straw yield, harvest index, submitted to different treatments of soybean seeds in the control of soil pathogens

\begin{tabular}{llllll}
\hline \multirow{2}{*}{ Treatments } & \multicolumn{5}{c}{ Variables } \\
\cline { 2 - 5 } & $\mathrm{GY}\left(\mathrm{kg} \mathrm{ha}^{-1}\right)$ & $\mathrm{DI}(\%)$ & $\mathrm{ABY}\left(\mathrm{kg} \mathrm{ha}^{-1}\right)$ & $\mathrm{SY}\left(\mathrm{kg} \mathrm{ha}^{-1}\right)$ & $\mathrm{HI}(\%)$ \\
\hline 3 - Cruiser+MaximXL+Standak+SYS LL & $4451 \mathrm{a}$ & $58 \mathrm{ab}$ & $13059 \mathrm{a}$ & $8818 \mathrm{a}$ & $52 \mathrm{a}$ \\
4- Cruiser+MaximXL+Standak+Trichodermil+SYS LL & $4227 \mathrm{ab}$ & $42 \mathrm{~b}$ & $12071 \mathrm{a}$ & $7932 \mathrm{a}$ & $50 \mathrm{a}$ \\
2 - Cruiser+MaximXL+Standak+Trichodermil & $3913 \mathrm{bc}$ & $65 \mathrm{ab}$ & $12072 \mathrm{a}$ & $8491 \mathrm{a}$ & $48 \mathrm{a}$ \\
1 - Cruiser+MaximXL+Standak & $3795 \mathrm{c}$ & $74 \mathrm{a}$ & $12217 \mathrm{a}$ & $8349 \mathrm{a}$ & $44 \mathrm{a}$ \\
Average Overall & 4074 & 60 & 13524.5 & 8397.5 & 48 \\
CV $(\%)$ & 4 & 21 & 6 & 10 & 11
\end{tabular}

Note. Means with different letters in a column are statistically different $(\mathrm{p} \leq 0.05)$. CV (\%): Coefficient of variation. GY: Grain yield; DI: Diseases incidence; ABY: Apparent biological yield; SY: Straw yield; HI: Harvest index.

Table 3 shows the control (Tiametoxan + Fludioxonil + Fipronil) had higher incidence of pathogens and did not statistically differ from the treatments containing these active principles and the biological product Trichoderma harzianum (Tiametoxan + Fludioxonil + Fipronil + Trichoderma harzianum) and Bradyrhizobium elkanii (Tiametoxan + Fludioxonil + Fipronil + Bradyrhizobium elkanii). The lowest incidence of pathogens occurred in the treatment co-inoculated with the biological products Trichoderma harzianum and Bradyrhizobium elkanii (Tiametoxan + Fludioxonil + Trichoderma harzianum + Bradyrhizobium elkanii), which did not statistically differ from the treatments that added Trichoderma harzianum (Tiametoxan + Fludioxonil + Fipronil + Trichoderma harzianum) and Bradyrhizobium elkanii (Tiametoxan + Fludioxonil + Fipronil + Bradyrhizobium elkanii). However, both were higher than the control, demonstrating the effectiveness of Trichoderma harzianum and Bradyrhizobium elkanii at protecting the plants from attack by soil pathogens.

Of the 225 plants evaluated by treatment to estimate the percentage of disease incidence, treatment 1 had a total number of 160 diseased plants, and treatment 2, 3 and 4 had 176, 102 and 115 diseased plants, respectively. These diseased plants had a $100 \%$ incidence of the pathogen Macrophomina phaseolina and an average of $20 \%$ of the pathogen Fusarium spp., in all evaluated treatments.

Trichoderma spp. act against antagonistic fungi and bacteria in soybean plants, and certain lineages have a stimulating effect on the growth and flowering of plants (Hoyos-Carvajal et al., 2009). Their addition to autoclaved soil increased emergence and dry material of tomato and tobacco (Windham et al., 1986; Fernandes et al., 2014). Another species that benefits from using microorganisms is cotton, which had a higher germination percentage when treated with $T$. harzianum, carboxin + thiram and carbendazin + thiram (Faria et al., 2003; Machado et al., 2012).

For the variables apparent biological yield, straw yield and harvest index, variation among the treatments was not observed. The variable legumes per healthy plant was higher for the treatments that included biological strains of fungi and bacteria, but the treatments did not statistically differ. The chemical treatment Tiametoxan + Fludioxonil + Fipronil had the lowest number of legumes (Table 4). GHP = Number of grains of healthy plants; GDP $=$ Number of grains of diseased plants; LHP $=$ Number of legumes of healthy plants; LDP $=$ Number of legumes of diseased plants. 
Table 4. Number of legumes of healthy plants, number of legumes of diseased plants, number of grains of healthy plants, number of legumes of diseased plants, submitted to different treatments of soybean seeds in the control of soil pathogens

\begin{tabular}{|c|c|c|c|c|}
\hline \multirow{3}{*}{ Treatments } & \multicolumn{4}{|c|}{ Variables } \\
\hline & \multicolumn{2}{|c|}{ NLP } & \multicolumn{2}{|c|}{ NGP } \\
\hline & HP & DP & HP & DP \\
\hline 3 - Cruiser+MaximXL+Standak+SYS LL & $84 \mathrm{a}$ & $64 \mathrm{a}$ & $182 \mathrm{a}$ & 139 a \\
\hline 4 - Cruiser+MaximXL+Standak+Trichodermil+SYS LL & $92 \mathrm{a}$ & $43 \mathrm{~b}$ & $178 \mathrm{a}$ & $96 \mathrm{bc}$ \\
\hline 2 - Cruiser+MaximXL+Standak+Trichodermil & $88 \mathrm{a}$ & $58 \mathrm{ab}$ & $202 \mathrm{a}$ & $118 \mathrm{ab}$ \\
\hline 1 - Cruiser+MaximXL+Standak & $53 \mathrm{~b}$ & $47 \mathrm{ab}$ & $100 \mathrm{~b}$ & $74 \mathrm{c}$ \\
\hline Average Overall & 79 & 53 & 165 & 106 \\
\hline CV (\%) & 7 & 14 & 10 & 16 \\
\hline
\end{tabular}

Note. Means with different letters in a column are statistically different $(\mathrm{p} \leq 0.05)$. CV (\%): Coefficient of variation; NLP: Number of legumes of plants; NGP: Number of grains of plants; HP: Healthy plants; DP: Diseased plants.

The number of legumes per plant or per area is the most important component when looking for increased grain yield. This is because the number of legumes varies greatly and can be influenced by phytosanitary management and environmental conditions due to the phenotypic plasticity of soybeans. In addition, the quantity of legumes depends on the quantity of flowers produced and pollinated during the reproductive period of the crop (Krüger et al., 2011).

The analysis of the number of legumes on the diseased plants showed that the treatment Tiametoxan + Fludioxonil + Fipronil + Bradyrhizobium elkanii had a higher number of legumes per plant, but did not statistically differ from the Tiametoxan + Fludioxonil + Fipronil + Trichoderma harzianum and Tiametoxan + Fludioxonil + Fipronil treatments. The treatment with the lowest number of legumes was Tiametoxan + Fludioxonil + Fipronil + Trichoderma harzianum + Bradyrhizobium elkanii.

The nodule count conducted in phase $\mathrm{R}_{2}$ (full flowering) revealed a higher number of legumes per plant for the treatment with SYS LL (B. elkanii + LCO). This result indicates that nodulation during full flowering is directly linked to symbiotic nitrogen fixation for grain production, due to the high nutritional demand to produce protein that represents about $46 \%$ of the seed's weight. In a similar study, Brandelero, Peixoto, and Ralisch (2009) found there was a significant correlation between grain yield of soybean cultivars and number and mass of nodules, and demonstrated that more than $40 \%$ of the yield was correlated to nodulation.

For the variable grains per healthy plant the treatments were superior compared to the control, demonstrating that using the microorganisms Bradyrhizobium and Trichoderma, besides keeping the soybeans sanitary by controlling soil pathogens, helps increase grain productivity. The same thing happened for grains of diseased plants, where the control that was not inoculated with the bacteria Bradyrhizobium or the biological fungicide Trichoderma had the lowest number of grains. This fact suggests that using Bradyrhizobium to treat seeds promotes an increase in N2 biological fixation by the plant and an increase in the production and translocation of carbohydrates to the seeds, favoring productivity. Trichoderma offers a competitive advantage in the colonization of the spermosphere and seedling roots, so that seedlings avoid parasitic attack (Mertz et al., 2009; Machado et al., 2012), which justifies the lower severity of disease and higher grain yield for the treatments that included it.

Among the yield components, the number of grains per legume was the least variable considering the treatment combinations. This demonstrates a uniformity of genetic improvement in the search for more productive plants, and that the plants have, on average, two seeds per legume. However, the incidence of pathogens on the crop can decrease the necessary intake of nutrients, reducing the number seeds per legume (Mertz et al., 2009; Danelli et al., 2011).

There was no significant difference between the average grain mass of healthy plants and diseased plants (Table 5), which is justified by the strong genetic dependence of this component that responded little to the environmental conditions in the study. The same occurred for the weight of the healthy plants and weight of the diseased plants, which did not statistically differ; the plants maintained their stature under both conditions and varied only in the dry weight of the legumes due to the different seed treatments used. 
Table 5. Average mass grains healthy plants, average mass grains diseased plants, weight healthy plant, weight diseased plant, submitted to different treatments of soybean seeds in the control of soil pathogens.

\begin{tabular}{|c|c|c|c|c|}
\hline \multirow{3}{*}{ Treatments } & \multicolumn{4}{|c|}{ Variables } \\
\hline & \multicolumn{2}{|c|}{ MTG } & \multicolumn{2}{|c|}{ MP } \\
\hline & HP & DP & $\mathrm{HP}$ & DP \\
\hline 3 - Cruiser+MaximXL+Standak+SYS LL & $159 \mathrm{a}$ & $174 \mathrm{a}$ & $23 \mathrm{a}$ & $16 \mathrm{a}$ \\
\hline 4 - Cruiser+MaximXL+Standak+Trichodermil+SYS LL & $159 \mathrm{a}$ & $155 \mathrm{a}$ & $26 \mathrm{a}$ & $12 \mathrm{a}$ \\
\hline 2 - Cruiser+MaximXL+Standak+Trichodermil & $156 \mathrm{a}$ & $160 \mathrm{a}$ & $21 \mathrm{a}$ & $16 \mathrm{a}$ \\
\hline 1 - Cruiser+MaximXL+Standak & $155 \mathrm{a}$ & $173 \mathrm{a}$ & $20 \mathrm{a}$ & $13 \mathrm{a}$ \\
\hline Average Overall & 157 & 171 & 22 & 14 \\
\hline $\mathrm{CV}(\%)$ & 6 & 4 & 14 & 12 \\
\hline
\end{tabular}

Note. Means with different letters in a column are statistically different $(\mathrm{p} \leq 0.05)$. CV (\%): Coefficient of variation; MTG: Mass of a thousand grains; MP: Mass of plants; HP: Healthy plants; DP: Diseased plants.

To elucidate the relationship between the base characters in the yield components of soybeans, Table 6 presents the correlation analysis for the variables analyzed in this study. The coefficient of determination was high $(0.80)$ for most of the variables, indicating these data are well associated.

Table 6. Coefficients of the productivity correlation and components of soybean yield.

\begin{tabular}{|c|c|c|c|c|c|c|c|c|c|c|c|c|c|}
\hline & GY & $\mathrm{HI}$ & $\mathrm{ABY}$ & SY & $\mathrm{HI}$ & LHP & LDP & GHP & GDP & MTGHP & MTGDP & WHP & WDP \\
\hline \multicolumn{14}{|l|}{ GY (Kg/ha) } \\
\hline DI (\%) & -0.677 & & & & & & & & & & & & \\
\hline $\mathrm{ABY}(\mathrm{kg} / \mathrm{ha})$ & 0.720 & 0.019 & & & & & & & & & & & \\
\hline $\mathrm{SY}(\mathrm{Kg} / \mathrm{ha})$ & 0.261 & 0.492 & 0.781 & & & & & & & & & & \\
\hline HI (\%) & 0.943 & -0.718 & 0.576 & 0.251 & & & & & & & & & \\
\hline $\operatorname{LHP}\left(\mathrm{n}^{\circ}\right)$ & 0.606 & -0.779 & 0.343 & -0.094 & 0.820 & & & & & & & & \\
\hline $\operatorname{LDP}\left(\mathrm{n}^{0}\right)$ & 0.402 & 0.252 & 0.724 & 0.940 & 0.483 & 0.243 & & & & & & & \\
\hline $\operatorname{GHP}\left(\mathrm{n}^{\circ}\right)$ & 0.511 & -0.545 & 0.106 & 0.156 & 0.767 & 0.949 & 0.484 & & & & & & \\
\hline $\operatorname{GDP}\left(\mathrm{n}^{\circ}\right)$ & 0.711 & -0.240 & 0.679 & 0.687 & 0.831 & 0.651 & 0.877 & 0.782 & & & & & \\
\hline MTGHP (g) & $0.951 *$ & -0.869 & 0.477 & -0.038 & 0.923 & 0.715 & 0.150 & 0.549 & 0.561 & & & & \\
\hline MTGDP (g) & 0.046 & 0.649 & 0.704 & 0.727 & -0.175 & -0.669 & 0.458 & -0.535 & 0.100 & -0.231 & & & \\
\hline $\mathrm{WHP}\left(\mathrm{n}^{\circ}\right)$ & 0.702 & $-0.992 *$ & 0.034 & -0.493 & 0.701 & 0.704 & -0.286 & 0.452 & 0.196 & 0.886 & -0.572 & & \\
\hline $\mathrm{WDP}\left(\mathrm{n}^{\circ}\right)$ & 0.207 & 0.338 & 0.528 & 0.884 & 0.355 & 0.252 & $0.967 *$ & 0.527 & 0.815 & -0.020 & 0.333 & -0.397 & \\
\hline CV $(\%)$ & 4 & 21 & 6 & 10 & 11 & 7 & 14 & 10 & 16 & 6 & 4 & 14 & 12 \\
\hline
\end{tabular}

Note. ${ }^{*} \mathrm{p} \leq 0.05$ (F test); ns: $\mathrm{p}>0.05$ (F test). CV: Coefficient of variation (\%); GY = Grain yield; DI = Diseases incidence; MTGHP = Mass of one thousand grains of healthy plants; MTGDP = Mass of one thousand grains of diseased plants; GHP $=$ Number of grains of healthy plants; GDP $=$ Number of grains of diseased plants; LHP $=$ Number of legumes of healthy plants; LDP $=$ Number of legumes of diseased plants; WHP $=$ Weight healthy plant; $\mathrm{WDP}=$ Weight diseased plant; $\mathrm{ABY}=$ Apparent biological yield; $\mathrm{SY}=$ Straw yield; $\mathrm{HI}=$ Harvest index .

In the correlation between mass of one thousand grains of healthy plants and grain yield (MTGHP $\times$ GY), the mass of healthy plants explains $95 \%$ of the grain yield among the treatments; this estimate is inflated by the indirect effect of the number of legumes per plant $(60.6 \%)$. Corroborating with the results of Nogueira et al. (2012) and Leite et al. (2016), that observed a significant and positive correlation between the character grain yield and number of legumes per plant in soybean, of $76.7 \%$ and $78.1 \%$, respectively. The selection of material via genetic improvement resulted in plants with greater grain mass, justifying the increase in grain yield. In addition, according to the results in this study, managing diseases can indirectly lead to a higher number of legumes, increasing the grain yield.

The weight of the healthy plants and disease incidence (WHP $\times \mathrm{DI}$ ), $\mathrm{r}=-0.99$, is negatively correlated at a significance of $5 \%$, which reiterates the importance of healthy plants in the crop that, in addition to producing more grain, are heavier and produce more dry material and organic material. The weight of the diseased plants 
and legumes of diseased plants (WDP $\times$ LDP), $r=0.97$, corresponds to the number of diseased legumes; however, the dry material of the legumes (straw) increases the total weight of the diseased plants.

Among all the yield components analyzed in this study, none had a higher correlation than the mass of one thousand grains of healthy plants. This component revealed effects of $95 \%$ on grain yield, indicating that over half of the total variation in grain yield was influenced by mass of a thousand grains. For Finoto et al. (2011), there was an increment of $22 \%$ in grain yeld of soybean in the treatments that ensured the sanity of plants. Similar results were also observed by Doreto et al. (2012), where the incidence of diseases in soybean plants reduced $18.6 \%$ of the mass of a thousand grains. And for Silva Júnior et al. (2009), the sanity of plants provided increases of $13 \%$ in the mass of a thousand grains and $125 \%$ in grain yield of soybean. The treatments with additional biological products, used individually or together (co-inoculated), had very significant values for average grain mass of healthy plants. Based on the evaluations, the direct effects of the components legumes of healthy plants and grains per healthy plant on grain yield are consistent enough to justify they have a closer cause-effect relationship with grain yield.

\section{Conclusion}

The microorganism Bradyrhizobium elkanii, and the co-inoculation of Bradyrhizobium elkanii and Trichoderma harzianum, resulted in higher grain yield and a significant difference between the direct components of the soybean yield compared to the chemical treatment, which can be explained by the higher nodulation index and lower disease incidence of the plants.

The components legumes per plant, grains per plant and mass of one thousand grains revealed the greatest cause and effect on grain yield. The treatment comprising the combination of Tiametoxan, Fludioxonil and Fipronil had a higher incidence of disease, lower grain yield and differed significantly in the direct evaluation of the legume yield per plant and grains per plant components.

\section{References}

Andrade, F. R., Nóbrega, J. C. A., Zuffo, A. M., Junior, V. P. M., Rambo, T. P., \& Santos, A. S. (2016). Características agronômicas e produtivas da soja cultivada em plantio convencional e cruzado. Revista de Agricultura, 91(1), 81-91. Retrieved from http://www.fealq.org.br/ojs/index.php/revistadeagricultura/article/ view/181

Brandelero, E. M., Peixoto, C. P., \& Ralisch, R. (2009). Nodulação de cultivares de soja e seus efeitos no rendimento de grãos. Ciência Agrária, 30(03), 581-588. https://doi.org/10.5433/1679-0359.2009v30n3p581

Brotman, Y., Landau, U., Cuadros-Inostroza, A., Takayuki, T., Fernie, A. R., Chet, I., Viterbo, A., \& Willmitzer, L. (2013). Trichoderma-plant root colonization: Escaping early plant defense responses and activation of the antioxidant machinery for saline stress tolerance. Plos Pathogens, 9(04), e1003221. https:/doi.org/ 10.1371/annotation/8b818c15-3fe0-4e56-9be2-e44fd1ed3fae

Caldarelli, C. E., Câmara, M. R. G., \& Sereia, V. J. (2009). O complexo agroindustrial da soja no Brasil e no Paraná: Exportações e competitividade no período 1990 a 2007. Organizações Rurais e Agroindustriais, 11(01), 1-20. Retrieved from https://www.researchgate.net/publication/46535131

Danelli, A. L., Fiallos, F. R. G., Tonin, R. B., \& Forcelini, C. A. (2011). Qualidade sanitária e fisiológica de sementes de soja em função do tratamento químico de sementes e foliar no campo. Revista Ciência y Tecnología, 4(02), 29-37. https://doi.org/10.18779/cyt.v4i2.68

Doreto, R. B. S., Gavassoni, W. L., Silva, E. F., Marchetti, M. E., Bacchi, L. M. A., \& Stefanello, F. F. (2012). Ferrugem asiática e produtividade da soja sob doses de potássio e fungicida, na safra 2007/08. Semina: Ciências Agrárias, 33(3), 941-952. https://doi.org/10.5433/1679-0359.2012v33n3p941

Dotto, D. M. R., Colpo, R. R., Iop, S. C. F., \& Cirolini, A. (2015). Percepção dos Consumidores de Soja e Derivados na Cidade de Júlio de Castilhos (RS)-Brasil. Revista em Agronegócio e Meio Ambiente, 8(03), 585-600. https://doi.org/10.17765/2176-9168.2015v8n3p585-600

Ethur, L. Z., Copatti, A. S., Silva, T. A., Cadore, L. S., \& Fresinghelli, J. C. F. (2016). Interferência do substrato vegetal na produção de escleródios de Sclerotinia sclerotiorum (Lib.) De Bary. Revista Agrarian, 9(32), 192-196. https://doi.org/10.30612/agrarian.v9i32.3130

Faria, A. Y. K., Albuquerque, M. C. F., \& Neto, D. C. (2003). Qualidade fisiológica de sementes de algodoeiro submetidas a tratamentos químico e biológico. Revista Brasileira de Sementes, 25(01), 121-127. https://doi.org/10.1590/S0101-31222003000100019 
Fernandes, R. H., Vieira, B. S., Fuga, C. A. G., \& Lopes, E. A. (2014). Pochonia chlamydosporia e Bacillus subtilis no controle de Meloidogyne incognita e M. javanica em mudas de tomateiro. Bioscience Journal, 30(1), 194-200. Retrieved from http://www.seer.ufu.br/index.php/biosciencejournal/article/view/18025

Finoto, E. L, Carrega, W. C., Sediyama, T., Albuquerque, J. A. A., Cecon, P. R., \& Reis, M. S. (2011). Efeito da aplicação de fungicida sobre caracteres agronômicos e severidade das doenças de final de ciclo na cultura da soja. Revista Agroambiente, 5(1), 44-49. https://doi.org/10.18227/1982-8470ragro.v5i1.418

Freitas, M. C. M. (2011). A cultura da soja no Brasil: O crescimento da produção brasileira e o surgimento de uma nova fronteira agrícola. Enciclopédia Biosfera, 7(12), 1-12. Retrieved from http://www.conhecer. org.br/enciclop/2011a/agrarias/a\%20cultura\%20da\%20soja.pdf

Hoyos-Carvajal, L., Orduz, S., \& Bissett, J. (2009). Growth stimulation in bean (Phaseolus vulgaris L.) by Trichoderma. Biological Control, 51(03), 409-416. https://doi.org/10.1016/j.biocontrol.2009.07.018

Krüger, C. A. M. B., Silva, J. A. G., Medeiros, S. L. P., Dalmago, G. A., Sartori, C. O., \& Schiavo, J. (2011). Arranjo de plantas na expressão dos componentes da produtividade de grãos de canola. Pesquisa Agropecuária Brasileira, 46(11), 1448-1453. https://doi.org/10.1590/S0100-204X2011001100005

Leite, W. S., Pavan, B. E., Filho, C. H. A. M., Neto, F. A., Oliveira, C. B., \& Feitosa, F. S. (2016). Estimativas de parâmetros genéticos, correlações e índices de seleção para seis caracteres agronômicos em linhagens F8 de soja. Comunicata Scientiae, 7(3), 302-310. https://doi.org/10.14295/CS.v7i3.1176

Lucca, A., Albrecht, L. P., Ávila, M. R., Scapim, C. A., Bio, F. E. I., \& Schuab, S. R. P. (2008). Qualidade fisiológica e sanitária das sementes de quinze cultivares de soja (Glycine max (L.) Merrill) colhidas na época normal e após o retardamento da colheita. Acta Scientiarum Agronomy, 25(02), 449-457. https://doi.org/10.4025/actasciagron.v25i2.2153

Machado, D. F. M., Parzianello, F. R., Silva, A. C. F., \& Antoniolli, Z. (2012). Trichoderma no Brasil: O fungo e o bioagente. Revista de Ciências Agrárias, 35(1), 274-288. Retrieved from http://www.scielo.mec.pt/ scielo.php?script $=$ sci_arttext\&pid $=$ S0871-018X2012000100026

Mertz, L. M., Henning, F. A., \& Zimmer, P. D. (2009). Bioprotetores e fungicidas químicos no tratamento de sementes de soja. Ciência Rural, 39(01), 13-18. https://doi.org/10.1590/S0103-84782009000100003

Nogueira, A. P. O., Sediyama, T., Souza, L. B., Hamawaki, O. T., Cruz, C. D., Pereira, D. G., \& Matsuo, E. (2012). Análise de trilha e correlações entre caracteres em soja cultivada em duas épocas de semeadura. Bioscience Journal, 28(6), 877-888. Retrieved from http://www.seer.ufu.br/index.php/biosciencejournal/ article/view/14576

Oliveira, R. L., Muniz, J. A., Andrade, M. J. B., \& Reis, R. L. (2009). Precisão experimental em ensaios com a cultura do feijão. Ciência e Agrotecnologia, 33(01), 113-119. https://doi.org/10.1590/S1413-7054200900 0100016

Pimentel-Gomes, F. (2009). Curso de estatística experimental (15th ed.) Piracicaba: Esalq.

Ribeiro, A. B. M., Bruzi, A. T., Zuffo, A. M., Zambiazzi, E. V., Soares, I. O., Vilela, N. J. D., ... Moreira, S. G. (2017). Productive performance of soybean cultivars grown in different plant densities. Ciência Rural, 47(7), e20160928. https://doi.org/10.1590/0103-8478cr20160928

Rocha, G. C., Neto, A. R., Cruz, S. J. S., Campos, G. W. B., Castro, A. C. O., \& Simon, G. A. (2017). Qualidade fisiológica de sementes de soja tratadas e armazenadas. Revista Cientifica, 1(5), 50-65. https://doi.org/ 10.29247/2358-260X.2017v4i1.p50-65

Santos, H. G., Jacomine, P. K. T., Anjos, L. H. C., Oliveira, V. A., Lumbreras, J. F., Coelho, M. R., ... Oliveira, J. B. (2013). Sistema brasileiro de classificação de solos (3rd ed.). Brasília: Embrapa Solos.

Schuab, S. R. P., De Lucca, A., Neto, J. D. B. F., Scapim, C. A., \& Meschede, D. K. (2008). Potencial fisiológico de sementes de soja e sua relação com a emergência das plântulas em campo. Acta Scientiarum Agronomy, 28(04), 553-561. Retrieved from http://eduem.uem.br/ojs/index.php/ActaSciAgron/article/download/ $928 / 928$

Silva Júnior, J., Rezende, P. M., Carvalho, E. A., Alves, E., \& Pozza, E. A. (2009). Efeito de fungicidas sistêmico e protetores aplicados em diferentes estádios fenológicos no controle da ferrugem asiática da soja. Ciência e Agrotecnologia, 33(3), 705-712. https://doi.org/10.1590/S1413-70542009000300007 
Silva, A. F., Carvalho, M. A. C., Schoninger, E. L., Monteiro, S., Caione, G., \& Santos, P. A. (2011). Doses de inoculante e nitrogênio na semeadura da soja em área de primeiro cultivo. Bioscience Journal, 27(03), 404-412. Retrieved from http://www.seer.ufu.br/index.php/biosciencejournal/article/viewFile/8067/7555

Silva, F. A. S., \& Azevedo, C. A. V. (2016). The Assistat Software Version 7.7 and its use in the analysis of experimental data. African Journal of Agricultural Research, 11(39), 3733-3740. https://doi.org/10.5897/ AJAR2016.11522

Teixeira, J. R. B., Ferraz, C. E. D. O., Couto Filho, J. C. F., Nery, A. A., \& Casotti, C. A. (2014). Intoxicações por agrotóxicos de uso agrícola em estados do Nordeste brasileiro, 1999-2009. Epidemiologia e Serviços de Saúde, 23(03), 497-508. https://doi.org/0.5123/S1679-49742014000300012

Windham, M. T., Elad, Y., \& Baker, R. (1986). A mechanism for increased plant growth induced by Trichoderma spp. Phytopathology, 76(05), 518-521. https://doi.org/10.1094/Phyto-76-518

Zilli, J. E., Marson, L. C., Marson, B. F., Gianluppi, V., Campo, R. J., \& Hungria, M. (2008). Inoculação de Bradyrhizobium em soja por pulverização em cobertura. Pesquisa Agropecuária Brasileira, 43(04), 541-544. https://doi.org/10.1590/S0100-204X2008000400014

\section{Copyrights}

Copyright for this article is retained by the author(s), with first publication rights granted to the journal.

This is an open-access article distributed under the terms and conditions of the Creative Commons Attribution license (http://creativecommons.org/licenses/by/4.0/). 